\title{
MECR Gene
}

National Cancer Institute

\section{Source}

National Cancer Institute. MECR Gene. NCI Thesaurus. Code C89008.

This gene may play a role in fatty acid synthesis. 